\title{
Analytical study of training needs of olive growers in various subject matter areas of olive cultivation in Uri Block of district Baramulla, J\&K, India
}

\author{
M.A. Beigh ${ }^{1}$, Quadri Javeed Ahmad Peer ${ }^{2 *}$, Sheikh Mehraj ${ }^{3}$ and F. Sibat ${ }^{1}$ \\ ${ }^{1,}$ Division of Extension Education \& Communication, Sher-e-Kashmir University of Agricultural Science \& \\ Technology, Kashmir (J\&K), INDIA \\ ${ }^{* 2}$ Division of Agriculture Statistics, Economics and Extension, FOA, Wadura, Sher-e-Kashmir, University of \\ Agricultural Science \& Technology Kashmir (J\&K), INDIA \\ ${ }^{3}$ Division of Fruit Science, Sher-e-Kashmir University of Agricultural Science \& Technology, Kashmir (J\&K), \\ INDIA \\ *Corresponding author. E-mail: qadrijavid2008@gmail.com
}

Received: November 8, 2014; Revised received: May 13, 2015; Accepted: June 7, 2015

\begin{abstract}
The main purpose of this study was to know the training needs of olive growers in different subject matter areas of olive cultivation undertaken in Uri block of district Baramulla of Jammu and Kashmir State. A sample size of 150 respondents was randomly selected from 5 villages and from each village 30 farmers were selected randomly. It was observed during the study that majority of farmers require training and with emphasis on latest transfer of technology in establishing olive farm, procurement of root stocks of improved varieties, soil management, proper spacing and planting, manures and fertilizers, irrigation and drainage, insect-pests and diseases, harvesting and marketing, etc. The area of insect-pests and diseases require high training need followed by soil management, selection of varieties, manures and fertilizers, harvesting and marketing, irrigation and drainage, establishing olive farm and procurement of root-stocks of improved varieties. Therefore, the study has highlighted the need for restructuring the training programme to benefit the olive growers in the region. Such an approach would boost production and generate additional income for the orchardists.
\end{abstract}

Keywords: Olive growers, Pest disease management, Training needs

\section{INTRODUCTION}

Olive commonly known as Zietune one of the world's oldest cultivated fruit crop. It is generally grown for its oil. The olive oil is used for pickles, ointments, illumination, condiments, medicines etc. The chemical composition of fresh/dried olive fruit is $45-55 \%$ water, $13-28 \%$ oil, 1.5-2.0 \% nitrogenous compounds, 8-24 $\%$ carbon compounds, 5-8 \% fiber and 1-2\% ash (USDA, 2011). In ancient time, olive tree was as precious as it was associated with religions and gods (Waterman and Lockwood 2007). Olive is grown in Italy, Spain, Greece and Portugal (FOA, 2011). In India it is grown in J\&K, H.P and U. P. In Jammu and Kashmir, olives can be grown in Poonch, Rajouri, Doda, Udhampur, Ramban, Reasi ,Kathua Govindpur, Ramban and District Baramulla (Anonymous, 2014a). Production of Olive is the most extensively cultivated fruit crop in the world. As per FOA (2011), the area under its cultivation has increased in the past 44 years, passing from 2.6 to 8.5 million hectares. In India, Jammu and Kashmir alone can searmark 30,000 hectares of area for Olive production (Anonymous, 2014). The total production of olive under Jammu and
Kashmir is approximately 45 metric tones. (Digest of Statistics, 2012-13). If we only take Jammu and Kashmir into account and make an effort to have a yield of about 20 to $25 \mathrm{q} / \mathrm{ha}$ from these pockets of Olive cultivation areas, the state can produce minimum 600,000 quintals of olives. Roughly 96, 000 quintals of Olive oil can be produced from the State of Jammu and Kashmir. In Kashmir, olive is grown in Uri block in district Baramulla. The state government and Department of horticulture is better striving for its cultivation on commercial scale and due to their, efforts, it is grown in seven villages in Uri block of district Baramulla (J\&K) (Anonymous, 2014). There is wide gap between the average yield obtained by farmers and that of potential yield. To narrow this gap, more emphasis should be given on training farmers in different subject matter areas of olive cultivation. Designing a training and development program involves a sequence of steps that can be grouped into five phases: needs assessment, instructional objectives, design, implementation and evaluation. To be effective and efficient, all training programs must start with a needs assessment (Wentling, 1992). Cultivation of olive is highly specialized and requires high level of 
expertise especially in the area of plant protection. Since there is very little scope for further increase in these areas, therefore, we have to train farmers and give special emphasis on transfer of latest technology in establishing olive orchards. One of the main reasons of low productivity is lack of technical know-how and skilled manpower. Thus, realizing the importance of training and to know the intensity of training needs of olive growers, the present study was under taken regarding training needs of olive growers in various subject matter areas of olive cultivation. Cultivation of olive is highly specialized and requires high level of expertise especially in the area of plant protection. Since there is very little scope for further increase in these areas, therefore, we have to train farmers and give special emphasis on transfer of latest technology in establishing olive orchards. One of the main reasons of low productivity is lack of technical know-how and skilled manpower. Training provides a systematic improvement of knowledge and skills which in turn helps the trainees to function effectively and efficiently in their given task on completion of the training (Gupta, 1982). Lynton and Pareek (1990) stated that training consists largely of well-organized opportunities for participants to acquire necessary understanding and skill. Farmer training is directed towards improving their job efficiency in farming. The kind of education we call as training is not for knowing more but behaving differently. (Stephen 2000), noted that, an effective training effort involves understanding how adults learn best. Thus, realizing the importance of training, present study was undertaken to know the intensity of training needs of olive growers.

\section{MATERIALS AND METHODS}

The study was conducted in the Uri block of district Baramulla $(\mathrm{J} \& \mathrm{~K})$ India. Out of the Uri block, five villages were selected randomly from Uri block. From each village, a manageable size of 30 olive growing farmers was selected randomly thus making total sample size of 150 farmers. An interview schedule based on the training needs in various subject matter areas and sub-areas of olive cultivation on a three point continuum i.e. most needed, needed and not needed, assigning arbitrary scores viz. 3,2 and 1, respectively was designed .This was pre-tested by interviewing thirty members who were not included, in the sample in order to know whether the respondents furnished the required information and whether the questions are clear and can be easily understood by the respondents. Necessary modifications in the questionnaire were made to make the questions comprehensible and practicable. The respondents were interviewed at their homes during their leisure time.

\section{RESULTS AND DISCUSSION}

Training needs in the area of establishing olive farm: It is evident from the figures present in Table 1 that the sub-area planting plan, planting time and spacing were ranked first with medium training need with a mean score of 2.03, whereas climatic requirement for growing olive had been placed at bottom with low training needs and mean of 1.15 . On further analysis, distribution of respondents of sub-area planting plan, planting time and spacing ranked first and $38.66 \%$ of growers reported it as most needed, $35.33 \%$ as not needed' and $26 \%$ as needed. The other sub-area soil texture and structure got second rank with mean score of 1.81 and medium training need. Size of Enterprise got third rank with mean score of 1.36 and low training need. Growing fences got 4 th rank with mean score of 1.27 and low, training need. Climatic requirement ranked at bottom with mean score of 1.15 and extent of training need was low

Training need in the area of selection of varieties: Data in Table 1 inferred that the sub-area 'Awareness regarding diseases, pests, resistant varieties' got first rank with and high training need. The least ranked sub-area was 'information regarding improved varieties with a mean score of 2.06 and medium extent of training need. It can also be seen from the above findings that $70 \%$ of the respondents indicated 'most needed' and $30 \%$ as needed for the training in the subarea awareness regarding diseases, pests and resistant varieties. Regarding the sub-area like Source of availability of varieties' attained Second rank with mean score of 2.32 having medium extent of training need. The sub-area which ranked lowest (a mean score of 2.70) was Information regarding improved varieties where 28.0.0 \% felt as most needed $50.66 \%$ as needed and. $21.33 \%$ as not needed.

Training need in the area of soil management: It is apparent from the data present in Table-1 that first rank for training was given to sub-area soil testing 'with mean score of 2.77 and having high extent of training need. On further analysis, $80 \%$ of the respondents reported that training is 'most needed' in the sub-area of Soil sampling for testing, $17.33 \%$ as needed and $2.66 \%$ as not needed. Interpretation of soil testing report' got second rank with mean score of 2.74 and having high extent of training need. The present study is in agreement with the finding of (Sanjeev et al., 2012) wherein they observed that the 46 per cent of the farmers adopted the soil management practices formulated by KVK in Manipur, India.

Training need in the area of manures and fertilizers: Under Fertilizers and Manures, Method of fertilizer application got highest rank with mean score of 2.52 and high extent of training need Table 1. The lowest rank was found in sub-area as choice of fertilizer application' with mean score of 2.01. The data in Table 1 also indicated that $58 \%$ of respondents expressed it as most needed, $36 \%$ as needed and $6 \%$ considered it as 'not needed, for subarea 'Method of fertilizer application. The sub-areas which ranked second and third were 'Micronutrient deficiencies and 
Table 1.Training needs of olive growers in various subject matter areas and sub-areas of olive cultivation. $(n=150)$

\begin{tabular}{|c|c|c|c|c|c|c|c|c|c|}
\hline \multirow[t]{2}{*}{ Area/ sub-area } & \multicolumn{2}{|l|}{ Most needed } & \multicolumn{2}{|l|}{ Needed } & \multicolumn{2}{|c|}{ Not needed } & \multirow{2}{*}{$\begin{array}{l}\text { Mean } \\
\text { score }\end{array}$} & \multirow{2}{*}{$\begin{array}{l}\text { Ra } \\
\text { nk }\end{array}$} & \multirow{2}{*}{$\begin{array}{l}\text { Extent } \\
\text { of train- } \\
\text { ing need }\end{array}$} \\
\hline & Frequency & $\%$ & Frequency & $\%$ & Frequency & $\%$ & & & \\
\hline \multicolumn{10}{|l|}{ Establishing olive farm } \\
\hline Size of Enterprise & 21 & 14.00 & 13 & 8.66 & 116 & 77.33 & 1.36 & 3 & $\mathrm{~L}$ \\
\hline Climatic Requirement & 9 & 6.00 & 5 & 3.33 & 136 & 90.66 & 1.15 & 5 & $\mathrm{~L}$ \\
\hline $\begin{array}{l}\text { Soil text. } \\
\text { And structure }\end{array}$ & 56 & 37.33 & 9 & 6.00 & 85 & 56.66 & 1.81 & 2 & M \\
\hline $\begin{array}{l}\text { Planting plan, time } \\
\text { and spacing }\end{array}$ & 58 & 38.66 & 39 & 26.00 & 53 & 35.33 & 2.03 & 1 & M \\
\hline Growing Fences & 16 & 10.66 & 8 & 5.33 & 126 & 84.00 & 1.27 & 4 & $\mathrm{~L}$ \\
\hline $\begin{array}{l}\text { Selection of Varieties } \\
\text { Information regarding } \\
\text { improved Varieties }\end{array}$ & 42 & 28.00 & 76 & 50.66 & 32 & 21.33 & 2.06 & 3 & M \\
\hline $\begin{array}{l}\text { Source of Availability of } \\
\text { varieties }\end{array}$ & 51 & 34.00 & 96 & 64.00 & 03 & 2.00 & 2.32 & 2 & M \\
\hline $\begin{array}{l}\text { Awareness regarding } \\
\text { diseases/pests and resis- } \\
\text { tant varieties }\end{array}$ & 105 & 70.00 & 45 & 30.00 & & & 2.70 & 1 & $\mathrm{H}$ \\
\hline \multicolumn{10}{|l|}{ Soil management } \\
\hline Soil sampling analysis & 120 & 80.00 & 26 & 17.33 & 4 & 2.66 & 2.77 & 1 & $\mathrm{H}$ \\
\hline $\begin{array}{l}\text { Interpretation of test } \\
\text { report }\end{array}$ & 116 & 77.33 & 39 & 19.33 & 5 & 3.33 & 2.74 & 2 & $\mathrm{H}$ \\
\hline \multicolumn{10}{|c|}{ Application of manures and fertilizers } \\
\hline Use of organic manure & 48 & 32.00 & 69 & 46.00 & 35 & 22.00 & 2.10 & 3 & M \\
\hline $\begin{array}{l}\text { Choice of fertilizer } \\
\text { Application }\end{array}$ & 47 & 31.33 & 58 & 38.66 & 45 & 30.00 & 2.01 & 4 & M \\
\hline $\begin{array}{l}\text { Method of fertilizer } \\
\text { Application }\end{array}$ & 87 & 58.00 & 54 & 36.00 & 9 & 6.00 & 2.52 & 1 & $\mathrm{H}$ \\
\hline $\begin{array}{l}\text { Micronutrient } \\
\text { deficiency and their } \\
\text { Management } \\
\text { Irrigation and drainage }\end{array}$ & 79 & 52.66 & 48 & 32.00 & 23 & 15.33 & 2.37 & 2 & $\mathrm{H}$ \\
\hline $\begin{array}{l}\text { Water requirement of } \\
\text { olive }\end{array}$ & 28 & 18.66 & 94 & 62.66 & 28 & 18.66 & 2.00 & 3 & M \\
\hline $\begin{array}{l}\text { Taking water } \\
\text { sample for testing }\end{array}$ & 59 & 39.33 & 87 & 58.00 & 04 & 2.66 & 2.37 & 1 & $\mathrm{H}$ \\
\hline $\begin{array}{l}\text { Factors affecting wa- } \\
\text { ter requirement }\end{array}$ & 32 & 21.33 & 56 & 37.33 & 62 & 41.33 & 1.80 & 4 & M \\
\hline $\begin{array}{l}\text { Water logging } \\
\text { problems \&drainage } \\
\text { techniques }\end{array}$ & 12 & 8.00 & 32 & 21.33 & 106 & 70.6 & 1.37 & 5 & $\mathrm{~L}$ \\
\hline $\begin{array}{l}\text { Time interval of } \\
\text { Irrigation and method } \\
\text { Irrigation }\end{array}$ & 43 & 28.66 & 88 & 58.66 & 19 & 12.66 & 2.16 & 2 & M \\
\hline Insect-pests and disease & & & & & & & & & \\
\hline $\begin{array}{l}\text { Identification of } \\
\text { insect-pests and dis- } \\
\text { eases }\end{array}$ & 104 & 69.33 & 46 & 30.66 & - & - & 2.69 & 4 & $\mathrm{H}$ \\
\hline $\begin{array}{l}\text { Causes of spread of } \\
\text { insect- pests and } \\
\text { diseases }\end{array}$ & 122 & 81.33 & 28 & 18.66 & & & 2.81 & 2 & $\mathrm{H}$ \\
\hline $\begin{array}{l}\text { Time-and method of } \\
\text { controlling insect- } \\
\text { pests and diseases }\end{array}$ & 138 & 92.00 & 12 & 8.00 & & & 2.92 & 1 & $\mathrm{H}$ \\
\hline $\begin{array}{l}\text { Awareness about the } \\
\text { use of insecticide and } \\
\text { pesticides in olive }\end{array}$ & 119 & 79.33 & 31 & 20.66 & & & 2.79 & 3 & $\mathrm{H}$ \\
\hline
\end{tabular}


Contd.........

\begin{tabular}{|c|c|c|c|c|c|c|c|c|c|}
\hline $\begin{array}{l}\text { Handling of insecticide and } \\
\text { Pesticides }\end{array}$ & 98 & 65.33 & 52 & 34.66 & & & 2.65 & 5 & $\mathrm{H}$ \\
\hline $\begin{array}{l}\text { Residual effect of } \\
\text { Insecticide and Pesticides }\end{array}$ & 92 & 61.33 & 58 & 38.66 & & & 2.61 & 6 & $\mathrm{H}$ \\
\hline \multicolumn{10}{|l|}{ Harvesting and Marketing } \\
\hline $\begin{array}{l}\text { Time and method of picking } \\
\text { fruits }\end{array}$ & 35 & 23.33 & 103 & 68.66 & 12 & 8.00 & 2.15 & 1.5 & M \\
\hline $\begin{array}{l}\text { Functions performed } \\
\text { In marketing and ways olive } \\
\text { sold }\end{array}$ & 31 & 20.66 & 109 & 72.66 & 10 & 6.66 & 2.14 & 2 & M \\
\hline Market preferences and prices & 29 & 19.33 & 115 & 76.66 & 6 & 4.00 & 2.15 & 1.5 & $\mathrm{M}$ \\
\hline $\begin{array}{l}\text { Average training needs score } \\
\text { Average training needs score }\end{array}$ & of 1 & $\begin{array}{l}\text { g need } \\
1 .\end{array}$ & $\begin{array}{l}\text { ow } \\
0<1.74\end{array}$ & & $\begin{array}{r}1 \\
1.7\end{array}$ & $\begin{array}{l}\text { lium } \\
<2.33\end{array}$ & & 2.33 & \\
\hline
\end{tabular}

their management and Use of organic manures (compost /FYM) with mean score of 2.37 and 2.10 and high and medium extent of training needs, respectively. On further analysis, the sub-area which got lowest rank is Choice of fertilizer application for which $30 \%$ of respondents reported it as not needed, $38.66 \%$ as needed and $31.33 \%$ as most needed.

Training need in the area of irrigation and drainage: The data present in Table 1 indicated that the sub-area Taking water sample for testing got highest rank with a mean score of 2.37 and high extent of training need. The sub-area 'Water logging problems and drainage techniques' was ranked at bottom indicating 'low' extent of training need with a mean score of 1.37. The perusal of data in Table 1 revealed that $39.33 \%$ of the respondents indicated it as 'most needed. $58 \%$ as needed and only $2.66 \%$ of the olive growers considered it as 'not needed'. On further analysis second, third and fourth rank was given to 'Time interval of irrigation and method of irrigation', Water requirement of olive crop' and 'Factors influencing water requirement (soil type, soil moisture, plant type, climatic conditions, etc.) with mean score of 2.16, 2.00 and 1.80, respectively and medium extent of training needs in all the three cases. The last rank (5th) was given to sub-area Water logging problems and drainage techniques' where $70.66 \%$ of the respondents indicating it as 'not needed, $21.33 \%$ as 'needed' and $8.00 \%$ reported it as most needed.

Training need in the area of insect-pests and diseases: The result showed in Table 1 that first rank for training needs in the area of Insect-pests and diseases has been credited to the sub-area time and method of controlling insect-pests and diseases with a mean score of 2.92 and high extent of training need. The sub-area residual effects of insecticides and pesticides' had been placed at bottom with a mean score of 2.61 and high extent of training need. On further observation it was found that $92 \%$ of the respondents reported it most needed and $8 \%$ as needed in the sub area Time and method of controlling insect-pests and diseases. The second and third rank was given to sub-areas Cause and spread of insect-pests and diseases and Awareness about use of various insecticides and pesticides with a mean score of 2.81 and 2.79 , respectively and having high extent of training needs in both cases. The fourth and fifth rank was given to sub-areas Identification of insect-pests and diseases and Handling of insecticides and pesticides with a mean score of 2.69 and 2.65, respectively and the extent of training need was high in both the cases. On further scrutiny, it was found that subarea Residual effect of insecticides and pesticides ranked at the bottom ad $61.33 \%$ of the olive growers expressed that training is 'most needed and $38.66 \%$ as 'needed' in this sub-area. The present study were supported by (Sanjeev et al.,2012) who had reported that training on integrated pest and disease management of the crops was the most important $(66 \%)$ need in plant protection . This is attributed to the

Table 2. Training needs of olive growers with respect to various areas of olive cultivation (overall) $(n=150)$.

\begin{tabular}{lccc}
\hline Areas & Mean score & Rank & Extent of training need \\
\hline Establishing olive farm & 1.32 & 7 & $\mathrm{~L}$ \\
Selection of varieties & 2.36 & 3 & $\mathrm{H}$ \\
Soil management & 2.43 & 2 & $\mathrm{H}$ \\
Application of manures and fertilizers & 2.25 & 4 & $\mathrm{M}$ \\
Irrigation and drainage & 1.94 & 6 & $\mathrm{M}$ \\
Insect-pests and diseases & 2.75 & 1 & $\mathrm{H}$ \\
Harvesting and marketing & 2.15 & 5 & $\mathrm{M}$ \\
Root stock production & 1.28 & 8 & $\mathrm{~L}$ \\
Average training needs score Extent of training need & Ledium & High \\
Average training needs score & Low & M & 2.26 to $<2.75$ \\
\hline
\end{tabular}


fact that farmers in valley areas of Manipur resort to over adoption of fertilizers and pesticides/fungicides. Impact of over adoption of those chemicals in the long run is ignored by them. With KVK interventions through extension activities, farmers in the study area have realized the importance of integrated pest management in agriculture for sustainable production and development. The findings are also in line with the findings of Iftikar et al. (2007), wherein they reported that about $60 \%$ of the farmers had no knowledge of fungicides like Benlate, Vitavax etc. which leads to the reduction in production of cotton.

Training need in the area of harvesting and marketing: Data revealed in Table 1 that in the area of Harvesting and marketing the sub-areas Time and method of picking olive fruits' and Market preferences and prices were ranked as first by the respondents with medium training need and a mean score of 2.15. Similarly the response pattern of the sub-area 'Functions performed in marketing and ways in which olive is sold' ranked at bottom with a mean score of 2.14 and medium extent of training need. The findings of the table- 1 also revealed that $23.33 \%$ of the respondents indicated training as most needed, $68.66 \%$ as 'needed and $8 \%$ as 'not needed in the sub area of Time and method of picking olive fruits. The data further revealed that $19.33 \%$ of the respondents expressed it as most needed and $76.66 \%$ as needed' in the sub area Marketing preferences and prices. Functions performed in marketing and ways in which olive is sold received last rank where only $20.66 \%$ of the respondents perceived it as 'most needed, $72.66 \%$ as needed and $6.66 \%$ as not needed.

Training needs of olive growers with respect to various areas of olive cultivation: The findings in relation to training needs (overall area wise) of the respondents are presented in Table 2. The area of Insect-pests and diseases had highest training need with a mean score of 2.75 and extent of training need was high. The second, third and fourth ranks were given to Soil management, Selection of varieties and Fertilizers and manures with mean score of 2.43, 2.36 and 2.25 and high and 'medium' extent of training need, respectively. The areas of Harvesting and marketing, Irrigation and drainage, Establishing olive farm and Root stock production have secured fifth, sixth, seventh and eighth rank with mean score of 2.15, 1.94, 1.32 and 1.28, respectively. The extent of training needs was 'medium' for fifth and sixth and 'low' for seventh and eighth in the olive cultivation. The present study is supported by Elfaki, (2000); Suleman (2004) and Banaga et al. (2008) who had reported that the main problems and constraints responsible for low productivity in Sudan were inadequate availability of agricultural inputs (in term of quality, quantity and affordability of prices), irrigation water management, pest and disease management, financing, lack of extension services, marketing and problems of harvest and post harvest processing.

\section{Conclusion}

It was concluded that training plays a great role for optimizing olive production and there is also a great need how to apply fertilizers and time of fertilizers application. The farmers were not aware of the judicious use of fertilizers and pesticides. The non judicious use of fertilizers had lead to loss of soil fertility and abrupt decrease of soil micro flora and fauna. As most of the orchardists in the region rely wholly on the pesticide dealers who are mostly illiterate and do not know the recommended dose of fertilizers and pesticides. Such training programmes would help to increase their per capita income of the farmers as well as the productivity of olice production.

\section{REFERENCES}

Anonymous. (2014). Annual Progress Report. Department of Horticulture J\&K Government, Srinagar, pp.1-2.

Digest of Statistics (2012-13). Directorate of Economics and Statistics. Government of J \& K, India Banaga, A. M., Elfaki, M.H. and. Ibraheem, I. M. (2008). The Gezira Scheme Training and Capacity Building Technical Committee. Training Needs Assessment for Gezira Scheme Farmers and Staff Report. Barakat, Gezira Scheme, Sudan. (In Arabic)

Elfaki. M. H. (2000). Agricultural Extension and Agricultural Research Linkages in the Sudan with Special Reference to Gezira. Ph.D Thesis. University of Gezira. Wad Medani, Sudan.

FAO (2011). Production year Book. Food and Agricultural organisation, Rome, Italy 55: 178.

Iftikhar, M., Ali, T. A. Munir, A. and A.A. Mann. (2007). Training needs assessment of cotton growers to meet the challenges of WTO by maintaining cotton quality in the Punjab Pakistan. Pakistan Journal of Agricultural Science, 44:641-645.

Gupta, M.P. (1982).Training needs of farmers in H.P. Indian Journal of Extension Education. 18(3\&4): 70-71. Lynton, R.P. and Pareek, U. (1990). Training for Development. Vistaar Publications, New Delhi.

Sajeev, M. V., Singha.A.K. and Venkatasubramanian, V. (2012). Training Needs of Farmers and Rural Youth:An Analysis of Manipur State, India. Journal Agricultural Science, 3: 103-112.

Suleman, S. A. (2004). Towards Generalization of the Agricultural Insurance Services in the Sudan. Sudan Currency Printing Press. Khartoum, Sudan. (in Arabic)

Stephen, L. (2000). Principles of Adult Learning. South Mountain Community College from VISION, Fall. From< http://teach-usda.ahnrit.vt.edu/principles of adult learning /pdf.> (Retrieved September 24, 2009).

US Department of Agriculture (USDA) (2011). Nutrient date base for Standard Reference Release 18. Available at http: // www. Ars. Usdagov/ main/site-main. Htm ? mode code $=1235$.

Waterman, E. and Lockwood, B. (2007). Active Components and Clinical Applications of Olive Oil. Alternative Medicine Review, 12:331-342.

Wentling, T.L. (1992). Planning for Effective Training: A guide to curriculum development. Rome: FAO. 